\title{
Postštrukturálna reflexia rečových aktov: Derrida, Foucault, Deleuze a Guattari ${ }^{1}$
}

\author{
Jakub Kapičiak \\ Univerzita Karlova, CZ
}

\begin{abstract}
KAPIČIAK, J.: Poststructural Reflection of the Speech Acts: Derrida, Foucault, Deleuze and Guattari.

Philosophica Critica, vol. 5, 2019, no. 1, ISSN 1339-8970, pp. 15-28.
\end{abstract}

\begin{abstract}
Austin's speech act theory was transformed thanks to Derrida's deconstruction into Butler's conception of performative gender identity. That is a common interpretation of the "history" of the term performativity. This approach tends to overlook contribution of other poststructural philosophers such as Foucault, Deleuze and Guattari to the current debates on the contexts and meanings of the term. The present study scrutinizes reflections of the speech act theory by these authors. The aim is to shed more light on how is the linguistic dimension of speech acts related to its ethical or political dimensions. To do so, the paper focuses on the performative force and iterability of utterances.
\end{abstract}

Key words: Iterability - J. L. Austin - Performativity - Speech act theory - Utterance

\section{Úvod}

Teória rečových aktov, ako ju predstavil John Langshaw Austin v posmrtne vydaných prednáškach v knihe How to do things with words (Ako niečo robit' slovami, 1962), stojí na počiatku konštrukcie „dejín“ performativity v súčasnom teoretickom diskurze. V diachrónnej perspektíve sa teória performativity interpretuje ako lineárny pohyb na osi Austin Derrida - Butlerová, a teda ako pohyb od teórie rečových aktov k teórii

1 Štúdia by nenadobudla súčasnú podobu bez komentárov Mgr. Ondřeja Šveca, Ph.D a Mgr. Terezy Matějčkovej, Ph.D z Ústavu filosofie a religionistiky na Filozofickej fakulte Univerzity Karlovej. Touto cestou by som sa im za ne rád pod'akoval. 
performatívnej identity. ${ }^{2}$ Túto interpretáciu nemožno zavrhnút' ako nesprávnu, no je nevyhnutné uvedomit' si jej limity. Centrálnou sa pre túto interpretáciu stáva Derridova dekonštrukcia Austinovej koncepcie, ktorou predložil, aby bola každá výpoved' chápaná ako citácia už kedysi vyslovenej výpovede. Derrida tým otvoril priestor pre Butlerovej koncepciu pohlavia a rodu ako telesných citácií regulatívneho ideálu, pričom tento ideál je sám onými citáciami utváraný. Do úzadia sa dostávajú práce dalǎšch postštrukturálne premýšl'ajúcich autorov, akými sú Michel Foucault a Gillese Deleuze s Felixom Guattarim. Práve ich mysleniu sa chcem v tejto štúdii venovat'. Chcem sa ním zaoberat' najmä z dôvodu absencie uvedených autorov v spomínanom prístupe $\mathrm{k}$ „dejinám“ performativity a pokúsit’ sa vyplnit’ biele miesta v takýchto „dejinách“.

Najskôr stručne zhrniem Austinovu teóriu rečových aktov, čo zároveň poslúži pre základné vymedzenie používanej terminológie. Pokračovat' budem Derridovou dekonštrukciou Austina. Pozornost' budem venovat' hlavne motívom opakovania a performatívnej sily výpovedí, ktoré sa stanú kl'účové aj pre diskusiu prác Foucaulta, Deleuza a Guattariho. Vo svojej interpretácii sa zameriam na to, ako uvedení filozofi čím d’alej tým viac zdôrazňujú sociálno-politické aspekty rečových aktov. Práve s týmito aspektmi súvisí deklarované úsilie o vypíňanie bielych miest.

\section{Od konštatívu a performatívu k ilokučnému aktu a účinku}

Pre Austinovo myslenie je charakteristické neustále preverovanie a prehodnocovanie vlastných postulátov, ku ktorým predtým dospel po sérii trpezlivých úvah a analýz. ${ }^{3} \mathrm{~V}$ prvých kapitolách knihy Ako niečo robit' slovami zavádza opozíciu konštatív - performatív (Austin 2004, 12 - 24). Konštatív je výpoved', ktorá opisuje stav vecí a môže byt' pravdivá alebo nepravdivá. Naproti tomu performatív nič neopisuje, nič netvrdí, ale ide o rečový akt, t. j. o konanie slovami. Performatívmi sú napríklad sl'ub alebo ospravedlnenie. Tento druh výpovedí je určovaný svojou vydarenostou a nie pravdivostou. Podmienky pre vydarený performatív sú existencia

2 Vid' napr. Aurelius - Chenzghou - Helgason (2016, 12 - 14), Culler (2015, 105 -118), Schechner (2013, 123 - 158). Žiada sa pritom dodat', že ide iba o jednu z dvoch vetiev performativity, ktorá sa dá označit' ako lingvisticko-filozofická. Druhá vetva sa zvyčajne situuje do oblasti interakcií divadelnej praxe a teórie s antropológiou, sociológiou a teóriou a praxou výtvarného umenia druhej polovice 20. storočia. Vid' napr. Loxley (2007) alebo Schechner (2013). Nesmierne pôsobivú interpretáciu Austinovho štýlu ponúkla Shoshana Felman (2003). Na osobitosti Austinovho štýlu a na príbuznost' jeho písania s dekonštrukciou upozornili napr. Cavell (1995, 42 - 65), Fish (2004, 35 - 45) alebo Gustafsson (2011, 12 - 15). 
určitej konvencionálnej situácie, ktorá zahŕňa vyslovenie určitých slov osobou na to spôsobilou, pričom táto osoba rečový akt vykoná správne a úplne, ako to vyžaduje konvencia (tzv. podmienky $A$ a $B$ ). Zároveň by oná spôsobilá osoba mala mat’ konvenciou vyžadované pocity v priebehu i po vykonaní rečového aktu (tzv. podmienka $\Gamma$ ).

V nasledujúcich kapitolách Austin pátra po kritériách pre spolahlivú dištinkciu konštatívu a performatívu, no dospieva k záveru, že nie sú až v takej nezmieritel'nej opozícii, ako sa sprvoti nazdával. Bližším skúmaním podmienok $A, B$ a $\Gamma$ Austin prichádza k záveru, že pravdivost' a vydarenost' sa chiazmaticky podmieňujú: „[J]e to práve vydarenost' performatívu ,Ospravedlňujem sa', vd'aka ktorej je faktom to, že sa ospravedlňujem; a úspešnost' môjho ospravedlnenia závisí od vydarenosti performatívnej výpovede ,Ospravedlňujem sa'." (Austin 2004, 53) To znamená, že aj konštatív môže byt' nevydarený. Ak hovoriaci čosi tvrdí, no sám o tomto tvrdení nie je presvedčený, čím porušuje podmienky $\Gamma$.

Eróziu vlastných prvotných postulátov sa Austin usiluje vyriešit' pomocou pojmov lokučného, ilokučného a perlokučného aktu. Tieto tri druhy aktov môžu byt' troma dimenziami toho istého rečového aktu (Berta 2005, 553). Lokučný akt je vyslovením určitej vety s určitým zmyslom a referenciou, čo ústi do vzniku významu. Ilokučný akt je aktom s určitou účinnost'ou v rámci istej konvencie, napr. informovanie alebo varovanie. Perlokučný akt je dosahovanie účinnosti s prekročením hranice konvencionálnej komunikačnej procedúry, napr. presviedčanie alebo odstrašovanie (Austin 2004, 107). Ked’že sa význam tvorí už v lokučnom akte, každý lokučný akt je apriórne ilokučným, pretože už rozpoznanie a pochopenie významu je účinkom. Konvenciu, o ktorej v súvislosti s dosahovaním účinkov Austin píše, nazýva aj odozvou alebo dohrou. Napríklad v prípade slubu je dohrou jeho splnenie (Austin 2004, 114).

Po zavedení nových kategórii sa pre Austina jeho pôvodná opozícia zdá byt' neudržatel'nou a to najmä preto, že vykonanie ilokučného aktu súbežne znamená vykonanie aktu lokučného, čo vyvracia domnienku, že by jestvovala pevná hranica medzi sférou „čistého“ konania (ilokúcie, performatívu) a hovorenia (lokúcie, konštatívu). Demonštruje to na príklade tvrdenia ako vzorového prípadu konštatívu. Tvrdenie je ilokučným aktom, lebo nejde o vykonanie žiadneho iného fyzického aktu okrem hovorenia, čo platí aj pre ilokučné akty, akými sú varovanie alebo sl'ub. Tvrdenie tak definuje dosiahnutie účinku (pochopenie významu), rovnako ako je tomu pri každom inom iloučnom akte. Z tejto perpektívy sa "objektívne“ kritérium pravdivosti rozpadá. Jedno a to isté tvrdenie môže byt' pravdivé aj nepravdivé v závislosti od kontextu, v akom bolo vyslovené (Austin 
2004, 137 - 139). Pre tieto všetky dôvody Austin zas a znova kladie dôraz na komplexnost' rečovej situácie, t. j. na kontextuálnu situovanost' výpovede. ${ }^{4}$

\section{Dekonštruovaný Austin}

Jacques Derrida svoju esej Signature, événement, contexte (Signatúra, udalost', kontext, 1971), v ktorej prehodnocuje Austinovu teóriu, začína úvahou o komunikácii v západnej filozofickej tradícii (Derrida 1993, 277 - 292). Komunikácia je v tejto tradícii interpretovaná ako reprezentácia čohosi neprítomného. Táto neprítomnost' je však v písomnej komunikácii iná, než je tomu pri gestickej či ústnej komunikácii. Vzhladom na percepčné pole adresanta je neprítomný adresát. Klúčovou podmienkou sa tak pre komunikáciu stáva iterovatel'ná (opakovatel'ná) písomná značka - graféma. Graféma presahuje prítomnost' a stáva sa východiskom pre iteráciu v neprítomnosti, t. j. za horizontom empirického subjektu a kontextu (ako množiny prítomností konštituujúcich moment zapísania grafémy). Derrida prisudzuje graféme inherentný potenciál zlomu, potenciál spretŕhat' všetky svoje väzby s kontextom. Do starého metafyzického pojmu písma Derrida vrúbluje sémantické nuansy, čím dekonštruuje chápanie komunikácie v západnej filozofickej tradícii (Fišerová 2018, 70). Derrida teda píše o grafematických predikátoch komunikácie. Znamená to, že každý znak (chápaný ako graféma) má nielen v písomnej, ale i v gestickej a ústnej komunikácii určitú identitu, čo zaručuje jeho rozpoznatelnost' a tým pádom aj iterabilitu. Tým, že je prvok rozpoznatel'ný ako identický, môže dôjst' k jeho oddeleniu od neho samého a od kontextu. Znak (chápaný ako graféma) je teda možné citovat', odtŕhat' ho od pôvodného kontextu a vytvárat' kontexty nové.

Z tejto pozície pristupuje Derrida k Austinovi (Derrida 1993, 292 - 304), ktorého kritizuje za údajnú prítomnost' intencie ako teleologického centra komunikácie a taktiež za jeho relatívne marginálne poznámky o fikčných výpovediach. ${ }^{5}$ Fikčné výpovede Austin označil za citácie bežnej reči a považoval ich za nulitné performatívy (Austin 2004, 31, 102 - 103). Derrida takýto prístup k fikčným výpovediam vníma ako Austinov príklon k filozofickej tradícii interpretovat' písmo vo vztahu k reči ako sekundárne. Obdobne ako predtým vrúbil nuansy do pojmu písma, čím ho dekonštruoval, robí teraz z nevážnych citácií bežnej reči (a práve preto nevydarených

\footnotetext{
4 Porovnaj môj výklad Austinovej teórie s Berta (2005, 552 - 557) alebo Marvan $(2010,165-170)$.

Derridova kritika Austina viedla k známemu sporu s J. R. Searlom. Podstatu sporu zrekapituloval napr. Frank (2000, 383-392).
} 
performatívov) základnú podmienku vykonania akéhokol'vek rečového aktu (Fišerová 2018, 71 - 73). Derrida sa teda pýta, či by bol možný performatív bez iterability, ktorá štiepi jeho singularitu ako udalosti, a ktorá ho tým pádom oddel'uje od neho samého. Dôsledkom iterability chápanej ako citovatel'nost' je suspendácia absolútnej nadvlády intencie nad výpoved’ou, pretože s iteráciou výpovede dochádza k zlomu vo väzbách na kontexty, v ktorých sa predtým výpoved' objavila, čím sa pre ňu otvára možnost' objavit' sa v nových intenciou teleologicky nedeterminovatel'ných kontextoch.

\section{Performatívna sila podla Derridu}

S citovatel'nostou výpovedí úzko súvisí ich tzv. performatívna sila. Táto väzba sa ukazuje v Derridových úvahách o práve a spravodlivosti (Derrida 2002, 15 - 20). Performatívna sila je prítomná pri ustanovovaní právnych predpisov. Prítomnostou performatívnej sily v procese ustanovovania práva sa mieni absencia apriórnej vládnucej moci, jestvujúcej mimo práva, alebo pred jeho prijatím. Derrida zbavuje aj tento proces teleologickej intencie. Pôvod zakladajúcej autority zákona označuje za násilie bez základu. Autorita sa opiera výhrade sama o seba. S odvolaním na Pascala a Montaigna potom Derrida píše o mystickom základe autority.

Pôsobenie performatívnej sily Derrida identifikuje pri analýze subjektu americkej Deklarácie nezávislosti. Pýta sa, kto je subjektom podpísaným pod týmto dokumentom. Deklarácia nezávislosti síce je de facto podpísaná členmi kongresu, no tí sú de iure reprezentantmi l'udu. Za podpisom preto stojí l'ud, avšak ten až do chvíle podpisu deklarácie nejestvoval. Preto Derrida píše, že „signatár sa rodí z podpisu“ (Derrida 1986, 10). Podpis tak retroaktívne oprávňuje l'ud deklarovat' svoju nezávislost'. Jan Matonoha (2010, 26 - 27) to nazýva metalepsiou, zámenou dôsledku a príčiny, resp. chiazmatickou prešmyčkou dôsledku a príčiny s cielom naturalizovat' vlastný vznik. ${ }^{6}$

\section{Foucault a problematika výpovede}

Michel Foucault upozorňuje na obdobnú metalepsiu v L'archeologie du savoir (Archeológia vedenia, 1969), premýšlajúc o tom, čo tvorí jednotu diskurzu. Ako prvú vyvracia hypotézu, že by oným jednotiacim momentom

\footnotetext{
$6 \quad$ Ako som už naznačil v úvode, pre Judith Butler sa princípy citovatel'nosti a metalepsie stali ústrednými. V knihe Bodies that Matter (Závažné telá, 1993) sú telesné akty, prostredníctvom ktorých sa identita performatívne (s neustálym odkladom celistvosti) konštituuje, interpretované ako citácie mobilizujúceho zákona, ktorý vzniká až svojimi citáciami (vid’ Butlerová 2016, 30 - 36).
} 
mohol byt' objekt referencie výpovedí v diskurze. Dôvodí tým, že v skutočnosti sú práve objekty (ktorých sa výpovede dovolávajú) týmito výpoved'ami aj (trans)formované. Jednota diskurzu preto spočíva skôr v systéme pravidiel produkcie objektov výpoved’ami v určitom čase a priestore. Foucaulta tak zaujímajú princípy rozmiestňovania výpovedí v diskurze (Foucault 2002, 52 - 54).

Táto problematika súvisí s Foucaultovým osobitým chápaním výpovede. Nejde o izolovatel'nú jednotku stotožnitel'nú s vetou, tvrdením ani rečovým aktom. Výpoved' je vždy zasadená do týchto už existujúcich jednotiek (skupín znakov) ako ich funkcia či modalita. Takto chápanú výpoved' Foucault charakterizuje hlavne štyrmi príznakmi: (1) Výpoved' dáva vzniknút' vztaham medzi skupinami znakov a skupinami objektov; (2) určuje možné subjektové pozície; (3) je situovaná medzi iné výpovede ako jedinečný prvok a pritom (4) oplýva opakovatel'nou materialitou (Foucault 2002, 134 - 162).

Výpoved' v zmysle funkcie či modality existencie skupiny znakov nielenže formuje objekty, ale taktiež ustanovuje pravidlá ich formovania v diskurze. Okrem toho Foucault takto chápanou výpoved’ou vylučuje závislost' formovaných objektov od l'ubovolných intencionálnych rozhodnutí subjektu. Diskurz sa naproti tomu vonkajšími a vnútornými procedúrami zovzácňuje. Vnútorné procedúry môžu mat' viacero foriem, napr. komentár, autora či disciplínu. Ich ciel'om je eliminovat' výskyt náhody (Foucault 2006). Pokúsim sa to priblížim na príklade komentára. Každá spoločnost' opakuje a obmieňa určité, pre ňu dôležité, rozprávania. Môžu nimi byt' náboženské, právne alebo literárne texty. Komentár je posunom medzi týmito dôležitými primárnymi textami a textami sekundárnymi. Komentár ako posun síce umožňuje aj vznik nových diskurzov, ale hlavne chce „iba konečne vyslovit', čo bolo potichu vyjadrené inde" (Foucault 2006, 18). Foucault pokračuje takto: „Komentár zažehnáva náhodu diskurzu tak, že sa na nej zúčastňuje: dovol'uje síce povedat' niečo iné ako sám text, no len pod podmienkou, že práve tento text bude vyslovený a $\mathrm{v}$ istom zmysle zavŕšený." (Foucault 2006) Komentár chápaný ako opakovanie a posun je dôležitý nie pre svoj obsah, ale pre samu udalost’ výskytu, v ktorej spočíva novost' toho, čo už bolo povedané (Foucault 2006).

Zdá sa, že Foucault vo svojej práci naráža na obdobný problém, ako Derrida pri dekonštrukcii Austina, avšak bez toho, aby explicitne vychádzal z polemiky s teóriou rečových aktov. Mám na mysli problém iterability výpovede. Zatial' čo Derridu zaujíma najmä to, ako môže individuálna výpoved' spretŕhat' svoje predchádzajúce väzby, aby participovala na utváraní nového kontextu, Foucault väčšmi poukazuje na závažnost' 
týchto väzieb. Zároveň to neznamená, že by Foucault postuloval determinovanost' výpovede (v danom prípade komentára) primárnym textom ako teleologickým centrom. Neznamená to ani, že by Derrida postuloval každú singulárnu výpoved' ako novú teleologickú inštanciu. V myslení oboch filozofov vidíme, že singularita výpovede nie je absolútna. Ak by takou bola, nad'alej by reprodukovala teleologickú logiku. Singularita výpovede závisí od určitého súboru pravidelností, ktoré majú u oboch filozofov odlišnú povahu. U Derridu sú dané grafematickými predikátmi komunikácie. Pravidelnosti, ako o nich uvažuje Foucault, sa pokúsim priblížit' prostredníctvom Deleuzovho čítania Foucaulta. Chcem si tým zároveň pripravit' pôdu pre zdôraznenie konvergencie v myslení Foucaulta a Deleuza s Guattarim.

\section{Deleuze a Foucault v dialógu o výpovedi}

Pri Deleuzovom prístupe k Foucaultovi treba pamätat' na jeho stratégiu písania o iných autoroch. Najmä o tých, ktorých dielo nemá žiadny pevný význam, lebo ich úsilím bolo žit' a žitím mysliet', ako to formuloval Petr Prášek $(2018,14)$. Deleuzova stratégia sa preto dá interpretovat' ako napojenie sa na Foucaultovo myslenie s ciel'om mysliet' spolu s ním a nepátrat' po tom, čo autor hovorí, ale ako to pôsobí (Prášek 2018). Hoci táto formulácia pôsobí pomerne vzletne, Deleuze sa tu nepochybne ponára do toku myslenia filozofa, ktorého cielom bolo stávat' sa iným (Marcelli 1995, 19 - 23) a dostat' sa tak „k tomu, čo nehovorí $v$ tom, čo hovorí“ (Deleuze 2010,155).

Deleuze v súvislosti s Foucaultovým významom výpovede kladie dôraz na jej dve vlastnosti - vzácnost' a opakovatel'nost', vzájomne prepojené prostredníctvom materiality ako „konštitutívnej zložky samej výpovede“ (Foucault 2002,155). Vzácnost' výpovedí definuje Deleuze ich odlišnostou od tvrdení a viet. Na rozdiel od nich totiž výpovede charakterizuje skutočnost', t. j. platí iba to, čo bolo sformulované v určitom čase a priestore (Deleuze 2003, 12 - 13). Opakovatel'nost' výpovede umožňuje jej materialita, ktorá je určovaná priestorom distribúcie výpovede, rozložením singulárnych prvkov, poriadkom rozmiestnenia a vztahom k ustanovujúcemu prostrediu (Deleuze 2003, 23). Vzácne výpovede tak súčasne nie sú podmienené originalitou, pretože sú opakovatel'né. Dôvodom je, že Foucault diferencuje materialitu udalosti vypovedania a materialitu výpovede. Udalosti vypovedania majú isté konštanty (gramatické, sémantické, logické) umožňujúce rozpoznat' v nej vetu či tvrdenie. Z udalosti vypovedania sa tak oddel'uje opakovatel'ná forma, vd’aka čomu rôzne udalosti vypovedania môžu byt' jednou a tou istou výpoved'ou, čo predstavuje bod, v ktorom sa približuje Foucaultova koncepcia k tej Derridovej. Špecifikum 
opakovatel'nej materiality výpovede spočíva v tom, že nie je viazaná na fyzický časopriestor, ale naopak na premenlivý status objektu, určovaný inštitucionálnym režimom a preto je režim materiality výpovede skôr rádom inštitúcie, ktorý definuje možnosti návratu výpovede (Foucault 2002, 156 - 158). Zároveň je tu však aj problém vztahu výpovede k iným výpovediam pol'a jej pôsobnosti (Foucault 2002, 158 - 160). Podl'a Deleuza záleží na pravidelnostiach výpovedí vysielaných a distribuovaných v priestore výpovede sú záležitost'ou topológie a nie typológie (Deleuze 2003,14). Deleuze potom definuje Foucaultovu výpoved' ako funkciu či modalitu prostredníctvom priestorov, ktoré ju obklopujú. Ide o kolaterálny, korelatívny a komplementárny priestor.

Pod kolaterálnym priestorom má Deleuze na mysli, že „každá výpoved” je neoddelitel'ná od ostatných, heterogénnych výpovedí, s ktorými je spojená určitými pravidlami zmeny" (Deleuze 2003,17). Tieto pravidlá pritom pôsobia na rovnakej úrovni, na akej sa nachádzajú výpovede. Odlišujú sa tak od axiómu či kontextu. Korelatívny priestor je vzt'ahom výpovedí k subjektom, objektom a pojmom, pričom subjekty, objekty i pojmy sú funkcie odvodené z výpovede (Deleuze 2003,21). Na rozdiel od viet nie sú výpovede pevne späté s lingvistickým subjektom vypovedania. Pozície subjektu sú vo výpovediach premenlivé a tvoria jej čast', avšak nie jej centrum. Tá istá veta môže byt' rôznou výpoved’ou v závislosti od svojho použitia, napr. v literatúre, v parlamente, v súkromnom liste, napísaná sprejom na stenu a pod. Komplementárny priestor predstavuje vonkajší, nediskurzívny priestor inštitúcií, ktorý so sebou nesie výpovede odkazujúce k týmto inštitúciám. Deleuze vystríha pred tým, aby sme o vztahu inštitúcií a výpovedí uvažovali ako o vztahu označovania či kauzality. Píše o diagonálnom vztahu. Ten znamená, že vztáah diskurzívnej a nediskurzívnej oblasti určuje horizont vynorenia sa objektov, bez ktorého by pre ich zrod nebolo miesto (Deleuze 2003, 22-23). Aj tu je možné vidiet’ implicitnú výstrahu pred metalepsiou.

\section{Výpoved' ako rozkaz podla Deleuza a Guattariho}

Presun̆me sa teraz k avizovanej konvergencii v myslení Foucaulta a Deleuza s Guattarim. V jednej pasáži v knihe Mille plateaux (Tisíc plošín, 1980) filozofi definujú výpoved' ako rozkaz, pretože v prvom rade stanovuje pravidlá používania jazyka (Deleuze - Guattari 2010, 89 - 102). Podobne ako u Foucaulta aj tu sa informatívna a označujúca funkcia výpovede stáva problematickou a výpoved' sama sa väčšmi chápe ako funkcia. Azda by sa dalo povedat', že Foucaultovo chápanie výpovede dokonca preberajú (Charvát 2016, 112). Ked’že je výpoved’ rozkazom stanovujúcim 
pravidlá používania, reč je súborom týchto rozkazov. Reč tým pádom nefunguje na princípe označovania videnej vonkajšej empirickej reality, t. j. výpoved’ou sa neoznačuje čosi, čo l'udský subjekt videl vlastnými očami. ${ }^{7}$ Podmienkou pre vznik reči nie je očité svedectvo, ale započutie inej výpovede: „Reč sa neuspokojuje s tým, že ide od prvého k druhému, od niekoho, kto videl, k niekomu, kto nevidel, ale ide nevyhnutne od druhého $\mathrm{k}$ tretiemu, pričom ani jeden $\mathrm{z}$ nich nevidel. Práve $\mathrm{v}$ tomto zmysle je reč prenosom slova fungujúceho ako rozkaz, a nie sprostredkovaním nejakého znaku ako informácie“ (Deleuze - Guattari 2010, 91). Reč nie je žiadnou kópiou sveta, ale mapou, ktorá nielenže iba mechanicky nereprodukuje, ale navyše aktívne konštruuje. Reč ako mapa znamená nový organizujúci systém otvorený rozličným spôsobom recepcie a ako taká je modifikovatel'ná (Deleuze - Guattari 2010, 20). Preto dvojica chápe reč ako rizóm. Rizómom Deleuze s Guattarim označujú štruktúru a myslenie oprostené od jednotného organizujúceho princípu. V tomto prípade od princípu reprezentácie. Rizomatickú štruktúru charakterizujú hlavne decentralizácia a heterogenita. ${ }^{8}$

Pri svojom uvažovaní o výpovedi ako rozkaze a reči ako súbore týchto výpovedí-rozkazov sa dvojica obracia k teórii rečových aktov, lebo práve tam sa podla nich odkrývajú tzv. implicitné či nediskurzívne predpoklady reči. Implicitné predpoklady vyvierajú z imanentného vztahu medzi výpoved'ou a aktom. Tento vzt'ah je artikulovaný práve v ilokučnej oblasti, čiže v oblasti dosahovania účinku rečového aktu, ako to načrtol už Austin. ${ }^{9}$ Deleuze s Guattarim odmietajú, že by imanentný vztah výpovede a aktu pri vykonávaní rečového aktu bolo možné zablokovat’ v jazyku apriórne prítomnou štruktúrou subjektivity, pôsobením ktorej by bol rečový akt autoreferenčným, ako o tom teoretizoval Émile Benveniste (1974,

7 Zaujímavo pôsobia tieto postuláty dvojice myslitelov v súvislosti s neskoršou Deleuzovou interpretáciou Foucaulta, kde píše: „Výpovede však neznamenajú, pretože sa nevztahujú k niečomu a o to menej vyjadrujú nejaký subjekt, ale odkazujú iba k reči, $\mathrm{k}$ bytiu reči, ktoré im dáva celkom dostačujúce vlastné subjekty a objekty ako imanentné premenné“ (Deleuze 2002, 155).

8 Podrobne o rizóme autori píšu v prvej kapitole Tisícich plošín (Deleuze - Guattari 2010, 9 - 36), kde vyčleňujú súbor šiestich princípov, ktoré ho charakterizujú. Ide o princípy spojenia, heterogenity, multiplicity, asignifikantného prerušenia, kartografie a dekalkománie. V tomto odstavci som odkazoval primárne na princíp kartografie.

$9 \quad$ Ked' autori urobia z účinkov rečových aktov vnútorné akty reči, jazyk prestáva byt' kódom, čo vyústujuje k suspendácii rozlíšenia medzi langue a parole (Douglas 1996, 365 - 366). Niet abstraktných pravidiel jazyka uplatňovaných v reči. Pravidlá vznikajú v reči samej, vyslovovaním výpovedí-rozkazov a azda práve preto potom Deleuze s Guattarim prisudzujú taký význam pragmatike (Charvát 2016, 116 - 125). 
293 - 297). Naproti tomu, odvolávajúc sa na iného francúzskeho lingvistu, Oswalda Ducrota, píšu, že autoreferenčnost' výpovede a teda v nej obsiahnutá subjektivita vyplývajú z pôsobenia výpovede v sociálnej sfére (Deleuze - Guattari 2010, 92 - 93). Práve vtiahnutost' výpovede do sociálnej sféry znamená, že ilokučná oblast' je sotva čímsi nezávislým, ale naopak závisí od kolektívnych usporiadaní vypovedania, stojacimi za procesmi subjektivácie. Znamená to, že subjektivita prítomná vo výpovedi je výsledkom pôsobenia kolektívneho usporiadania vypovedania v sociálnej sfére. Rečový akt tak má nevyhnutne sociálnu povahu, ktorá suspenduje jeho potencialitu ako individuálneho vypovedania. Jeho sociálna povaha však nie je čímsi vonkajším, ale naopak, ide o formu akejsi internalizácie kolektívneho usporiadania: „[I]ndividuácia výpovede a subjektivácia vypovedania existuje iba v miere, v akej ju vyžaduje a určuje neosobné kolektívne usporiadanie." (Deleuze - Guattari 2010, 95) Autori ako príklad takéhoto kolektívneho usporiadania uvádzajú polopriamu reč, ktorá nerozlišuje medzi subjektmi, nepozostáva z individualizovaných výpovedí. Jestvuje výhradne ako kolektívne usporiadanie, ktoré určuje procesy subjektivácie a individualizácie a ich distribúcie v reči.

Proces subjektivácie z kolektívnych usporiadaní Deleuza s Guattarim osvetl'ujú prostredníctvom povahy rozkazu - vzt’ahom medzi výpoved’ou a implicitnými predpokladmi reči. Píšu, že tento vzt’ah vzniká v systéme imanentných aktov, definovaných súborom netelesných transformácií, t. j. vo svojej podstate netelesných atribútov pripisovaných telám; netelesnou transformáciou je napríklad náhla transformácia obvineného súdnym verdiktom na odsúdeného. Hoci sú tieto transformácie samy o sebe netelesné, vo vztahu k telu sú vnútorné (Deleuze - Guattari 2010, 95 - 97).

Ked' teda autori píšu o výpovediach-rozkazoch, mienia nimi implicitné predpoklady týchto netelesných transformácií a nie explicitné imperatívy. Dvojica ukazuje dôsledky v rovine subjektivácie (Deleuze - Guattari 2010, 100). Každá výpoved' kolektívneho usporiadania je nevyhnutne polopriamou rečou, ktorá vždy znamená prítomnost’ rozkazu v slove. Každá reč je polopriama a priama reč je iba fragmentom vybraným $\mathrm{z}$ mnohohlasej masy polopriamej reči. Individuálne hovorenie a písanie je preto iba akýmsi triedením a selekciou tejto polyfónie, ktorého výsledkom je zrod subjektu. Subjekt, resp. to, čo človek pocit’uje ako jeho vlastné „ja“ tak nie je ničím iným než rozkazom, t. j. netelesnou transformáciou seba samého na dovtedy nejestvujúci subjekt výpovede. Subjektu samého osebe tým pádom niet na telesnej úrovni. Jestvuje iba vo forme výsledku náhleho aktu pripísania netelesných atribútov telu. 


\section{Foucault a rečové akty}

Analýzou výpovede s funkciou rozkazu optikou rečových aktov sa Deleuze a Guattari dostávajú k etickým a politickým otázkam subjektivácie, čo zároveň predstavuje jednu z ústredných tém Foucaultovej filozofie. ${ }^{10}$ Netelesná transformácia indivídua na subjekt je v Deleuzovej a Guattariho práci uskutočňovaná v bežnej reči ako dôsledok jej vtiahnutosti do sféry sociálna. Ako ukázala autorská dvojica, tento aspekt sa zviditel'ňuje práve $\mathrm{v}$ rečových aktoch. Táto skutočnost' nasvecuje Foucaultov záujem o subjekt z trocha inej perspektívy. Dobre to naznačuje štúdia novozélandského filozofa edukácie Jamesa D. Marshalla (1999).

Marshall sa vo svojom texte podujal preskúmat' prepojenie medzi viacerými prístupmi k performativite - v teórii rečových aktov, u JeanaFrançoisa Lyotarda ${ }^{11}$ a Foucaulta. Marshall si vedno s Foucaultom kladie otázku, ako môže klasifikujúce tvrdenie o indivíduu vyústit' do jeho stotožnenia s týmto tvrdením. Svoju otázku situuje do prostredia vzdelávacej inštitúcie, školy, čím svoj záujem ohraničuje problematikou známkovania. Marshall interpretuje známkovanie ako hodnotiaci súd a tým pádom performatív a nie konštatív opisujúci stav vecí. Ked' známkovanie nazýva performatívom, zdôrazňuje, že ide o konštitutívny akt. Týmto aktom sa študentskej práci prisudzuje status. Napríklad trojka znamená, že je „dobrá/-ý“ a štvorka „dostatočná/-ý“ a pod. Podla Marshalla sa zároveň s prisúdením práci statusu „dobrá“ či „dostatočná", prisudzuje tento status aj študentovi.

Takto sa Marshall usiluje prepojit' Austinovo a Foucaultovo myslenie. Upozorňuje, že pre oboch filozofov sú dôležité okolnosti realizácie výpovede (známkovanie musí prebiehat' v rámci vyučovania, t. j. v inštitucionálnom kontexte vzdelávania), hovoriaci/známkujúci musí byt’ k tomuto aktu oprávnený ( $\mathrm{v}$ inštitucionálnom kontexte musí zastávat' pozíciu pedagóga), študent musí známku akceptovat' (musí akceptovat’ inštitucionálny rád vzdelávania). To, že spolu s klasifikáciou práce dochádza aj ku klasifikácii študenta Marshall vysvetl'uje tým, že známkovanie je ilokučným aktom s perlokučným účinkom. Pod perlokučným účinkom mieni študentovo presvedčenie, že nielen jeho práca je „dobrá“, ale aj on takým je. Odvolávajúc sa na Foucaulta dodáva, že študentovo presvedčenie zabezpečujú inštitucionálne procedúry, normalizujúce jeho status ako „dobrého“ či „dostatočného“ jedinca.

Vid' napr. Foucault (1991), Dreyfus - Rabinow (2002, 258 - 279).

11 Pokial' ide o Lyotarda, ako aj Marshalla, operujú s Lyotardovým chápaním performativity ako požiadavkou efektivity a výkonnosti systému, ktoré sú v kapitalizme uplatňované aj v systémoch vedy a vzdelávania. Vid' Lyotard (1993, 155 - 161). 
Marshall pri tejto svojej interpretácii nevdojak dospieva k otázke o hranici ilokučného a perlokučného aktu, ktorú si kládol už Austin. Ak by malo známkovanie ilokučný účinok, znamenalo by dohru v medziach konvencionálneho rámca pokusu objektívne zhodnotit' úroveň študentskej práce, avšak ak je jeho účinok skutočne perlokučný, tento rámec prekračuje a dôsledky sa môžu prejavit’ aj na pozícii študenta v inštitúcií. Zároveň je však známkovanie nástrojom usmerňovaným inštitúciou, čím sa potvrdzuje, že tým istým rečovým aktom je súčasne možné realizovat' lokučný, ilokučný i perlokučný akt. Po vzore Judith Butlerovej (2013) je následne možné dodat', že celý proces „presviedčania“ študenta o jeho vlastnostiach na základe oznámkovanej práce môže byt' vnímaný ako interpelácia subjektu Zákonom, ku ktorému subjekt tiahne afektívne puto.

\section{Záver}

Teória rečových aktov si všíma potenciál jazyka zasahovat' do materiálneho sveta. Takýto prístup k jazyku otvára priestor pre jeho uchopenie ako súčasti sociálno-politickej sféry. Jazyk sa prestáva chápat’ ako neutrálny nástroj reprezentácie vonkajšej reality. ${ }^{12} \mathrm{~V}$ štúdii som sa usiloval mapovat' práve tento prechod.

Nechcem tým však tvrdit', že teória rečových aktov je akýmsi východiskovým bodom postštrukturálneho myslenia. Pohyboval som sa v medziach „dejín“ performativity, ako som ich načrtol ešte v úvode. Zameral som sa preto na impulzy teórie rečových aktov, po ktorých je možné pátrat' v prácach analyzovaných autorov. Sústredil som sa na motívy opakovania a performatívnej sily výpovedí. Dajú sa identifikovat' u všetkých autorov (aj autorky), ktorými som sa v štúdii zaoberal.

U Austina sa uvedené motívy objavujú najmä v dôraze na konvencionalitu výpovedí. Tie akoby vždy opakovali existujúce konvencionálne situácie, pričom z týchto situácií vyplýva aj modalita účinku výpovede. Derrida si v danej súvislosti všíma, že výpovede chápané ako opakovanie konvencionálnych modelov môžu byt' uchopené ako citácie. Ako také sú nielen mechanickým opakovaním, ale ich opätovný výskyt je tým, čo ich diferencuje od svojho pôvodu, čím nadobúdajú performatívnu silu, silu konštruovat'. Táto sila pritom funguje vd’aka princípu metalepsie, ktorý naturalizuje skonštruovaný jav.

Obdobný princíp metalepsie je možné identifikovat' pri uvažovaní o motívoch opakovania a performatívnej sile aj v analyzovaných prácach Foucaulta, Deleuza a Guattariho. U Foucaulta som poukázal na to, že

12 Porovnaj pojmy jazykový obrat a konštruktivizmus v Matonoha a kol. (2017, $25-27,242-243)$. 
objekty sú iba zdanlivo zjednocujúcim prvkom diskurzu, pretože v skutočnosti sú objekty výpoved’ami diskurzu formované. Z citovanej práce Deleuza a Guattariho je zasa zrejmé, že podobným spôsobom dochádza aj k subjektivácii. V záverečnej časti som sa na príklade Marshallovho čítania Foucaulta cez prizmu teórie rečových aktov usiloval poukázat' na to, ako výpovede realizované $\mathrm{v}$ určitých inštitucionálnych podmienkach aktívne konštituujú identitu subjektov. Rád inštitúcie pritom zabezpečuje opakovanie výpovedí a tým i neustály proces konštrukcie. Práve tieto aspekty som považoval za zásadné pri pokuse o revíziu „dejín“ performativity ako priamočiareho pohybu od Austina k Derridovi až k Butlerovej.

\section{Literatúra}

AUREliUS, E. H. - CHENGzHOU, H. - HELGASON, J. (2016): Performativity in Literature: The Lund - Nanjing Seminars. In: E. H. Aurelius - H. Chengzhou J. Helgason (eds.): Performativity in Literature. Stockholm: KVHAA, 9 - 26.

BENVENISTE, É. (1974): Obščaja lingvistika. Prel. Ju. N. Karaulovová et al. Moskva: Progress.

BERTA, J. (2005): Rečové akty z aspektu filozoficko-lingvistického. In: Filozofia, $60(8), 551-572$.

BUTLER, J. (2013): Svědomí z nás všech činí subjekty. Preložil J. Fulka. In: Filosofický časopis, 61 (2), 237 - 256.

BUTLEROVÁ, J. (2016): Závažná těla: O materialitě a diskursivních mezích „pohlaví“. Preložil J. Fulka. Praha: Karolinum.

CAVELL, S. (1995): Philosophical Passages: Wittgenstein, Emerson, Austin, Derrida. Oxford - Cambridge: Blackwell.

CULLER, J. (2015): Krátký úvod do literární teorie. Preložil J. Bareš. Brno: Host.

DELEUZE, G. (2003): Foucault. Prel. Č. Pelikán. Praha: Hermann a synové.

DELEUZE, G. (2010): Pusté ostrovy a jiné texty: texty a rozhovory 1953 - 1974. Prel. M. Petř́ček a M. Marcelli. Praha: Herman a synové.

DELEUZE, G. - GUATTARI, F. (2010): Tisíc plošin. Prel. M. Caruccio Caporale. Praha: Herrmann a synové.

DERRIDA, J. (1986): Declaration of Independence. Preložili T. Keenan a T. Pepper. In: New Political Science, 7 (1), 7 - 15.

DERRIDA, J. (1993): Texty k dekonstrukci: práce z let 1967 - 1972. Prel. M. Petříček. Bratislava: Archa.

DERRIDA, J. (2002): Síla zákona: Mystický základ autority. Prel. M. Petříček. Praha: Oikoymenh.

DOUGLAS, T. (1996): It's Not What You Say, It's That You Say It: Speech, Performance, and Sense in Austin and Deleuze. In: Philosophy \& Rhetoric, 29 (4), 359 - 368.

DREYFUS, H. L. - RABINOW, P. (2002): Michel Foucault: Za hranicemi strukturalismu a hermeneutiky. Prel. J. Hasala a kol. Praha: Hermann a synové. 
FELMAN, S. (2003): The Scandal of The Speaking Body: Don Juan with J. L. Austin, or Seduction in Two Languages. Prel. C. Porter. Stanford: Stanford University Press.

FISH, S. (2004): S úctou věnuje autor. Prel. P. A. Bílek. Brno: Ústav pro českou literaturu AV ČR

FIŠEROVÁ, M. (2018): Písemní akt. Derrida a Searle o parazitické performativitě. In: Filozofia, 73 (1), 63 - 74.

FOUCAULT, M. (1991): Prečo študovat’ moc: otázka subjektu. Preložil M. Marcelli. In: E. Gál a M. Marcelli (eds.): Za zrkadlom moderny. Bratislava: Archa, 42 - 52.

FOUCAUlT, M. (2002): Archeologie vědění. Prel. Č. Pelikán. Praha: Hermann a synové.

FOUCAULT, M. (2006): Rád diskurzu. Prel. M. Marcelli. Bratislava: Agora.

FRANK, M. (2000): Co je neostrukturalismus? Prel. M. Petř́iček. Praha: SOFIS.

GUSTAFFSON, M. (2011): Introduction: Inheriting Austin. In: M. Gustaffson R. Sørli (eds.): The Philosophy of J. L. Austin. Oxford: Oxford University Press, $1-31$.

CHARVÁT, M. (2016): Gilles Deleuze: asignifikantní sémiotika. Praha: Togga

LOXLEY, J. (2007): Performativity. London - New York: Routledge.

LYOTARD, J.-F. (1993): O postmodernismu: Postmoderno vysvětlované dětem. Postmoderní situace. Prel. J. Pechar. Praha: Filosofický ústav AV ČR.

MARCELLI, M. (1995): Foucault alebo stat'sa iným. Bratislava: Archa.

MARSHALL, J. D. (1999): Performativity: Lyotard and Foucault Through Searle and Austin. In: Studies in Philosophy and Education, 18 (5), 309 - 317.

MARVAN, T. (2010): Otázka významu: Cesty analytickéfilosofie jazyka. Praha: Togga. MATONOHA, J. (2010): Pasti performativity: dělat, jako by se nic nedělo. In: O. Sládek (ed.): Performance - performativita. Praha: Ústav pro českou literaturu, $21-34$.

MATONOHA, J. A KOL. (2017): Za (de)konstruktivismem: Kritické koncepty (post) poststrukturální literární a kulturní teorie. Praha: Academia.

PRÁŠEK, P. (2018): Člověk v šíleném dění světa: Filosofie Gillesa Deleuze. Praha: Karolinum.

SCHECHNER, R. (2013): Performance Studies: An Introduction. London - New York: Routledge.

\section{Mgr. Jakub Kapičiak}

Univerzita Karlova

Filozofická fakulta

Ústav východoevropských studií

Nám. Jana Palacha 2

11638 Praha 1

Česká republika

kap.jakub@gmail.com 